\title{
As traduções de Huckleberry Finn à luz das normas de Toury ${ }^{1}$
}

\author{
Débora Landsberg e Paulo Henriques Britto*
}

\section{Introdução}

Segundo Paulo Henriques Britto, os falantes do português brasileiro e do inglês sempre tiveram posturas totalmente diferentes em relação à oralidade:

Por que é tão maior a distância entre o registro escrito e o falado no português do Brasil do que no inglês? Creio que o fenômeno se deva às maneiras opostas como os falantes do inglês e os do português encaram (ou, ao menos até recentemente, encaravam) seus respectivos idiomas. De modo geral, para os anglófonos, a língua pertence a seus falantes; a função dos dicionários é registrar as palavras que vão surgindo (...). Do mesmo modo, as gramáticas inglesas se dedicam mais a registrar do que a julgar. É claro que há uma norma culta, só que ela é vista como algo que se aplica apenas aos usos mais formais da língua: ao ensaio, à tese acadêmica, ao compêndio erudito, mas não à fala dos personagens dos romances e dos filmes. (...) [P]ara a maioria dos falantes do inglês, o idioma é um organismo vivo, e sua exuberância, sua profusão de dialetos e registros, é prova de vitalidade. A atitude tradicional dos brasileiros em relação à língua portuguesa é muito diferente, embora (...) ela tenha mudado nas últimas décadas, por obra dos escritores e jornalistas progressistas e de linguistas militantes, como Marcos Bagno. Mas até meados dos anos 1960 (...) a visão dominante era mais ou menos esta: a língua portuguesa, a última flor do Lácio, (...) tinha de ser cuidadosamente protegida de seus usuários. Ela não pertencia a nós, brasileiros comuns; pertencia aos portugueses, ou talvez aos grandes escritores portugueses e brasileiros mortos há no mínimo meio século, ou aos gramáticos e lexicógrafos e professores de português, aos quais cabia a tarefa de preservá-la em seu estado de pureza original. (Britto, 2012, p. 83-84)

\footnotetext{
${ }^{1}$ Agradecemos ao CNPq pelo auxílio financeiro que possibilitou a escrita deste artigo. Agradecemos também as críticas e sugestões da professora Marcia Martins.

* Débora Landsberg é mestre em Estudos da Linguagem, na linha de pesquisa Linguagem, Sentido e Tradução, pela PUC-Rio. Paulo Henriques Britto é Professor Associado do Departamento de Letras da PUC-Rio.
} 
Essa recente mudança de postura dos brasileiros teoricamente acarretou transformações no que concerne à tradução de diálogos em obras literárias ao longo das últimas décadas. Neste trabalho, examinaremos duas traduções, de diferentes épocas, de As aventuras de Huckleberry Finn - obra literária de Mark Twain marcada pela presença de diversos dialetos - a fim de averiguarmos como foram transpostas ao português. Partimos da hipótese de que, até poucas décadas atrás, os diálogos das obras literárias eram traduzidos como qualquer outra passagem da narrativa. Porém, com o tempo, as falas dos personagens adquiriram um tom cada vez mais natural, mais condizente com o linguajar oral do português brasileiro. Por ser um caso extremo, a comparação entre traduções de As aventuras de Huckleberry Finn pode nos servir de base para comprovarmos ou retificarmos tal impressão, sustentada também por John Milton:

\footnotetext{
As pesquisas de Milton (2002: 52-62) sobre traduções em português brasileiro de romances clássicos estrangeiros revelam que a anulação da oralidade em dialetos estigmatizados ou sem prestígio foi a tônica geral até pelo menos a década de 1970. Entretanto, percebem-se mudanças em relação a este comportamento conservador. Isto se deve em grande parte ao papel que a Linguística assumiu a partir do final dos anos 1960, lançando reflexões acerca do papel da língua e dos falantes, com ramificações de estudo em novas áreas como a Sociolinguística, ou seja, o estudo da língua em relação a fatores sociais (classe social, nível escolar, idade, sexo, origem étnica etc.), repensando as variedades linguísticas. Como reflexo disso - apesar da persistência da postura purista ainda fortemente disseminada - as disciplinas ou áreas do saber ligadas ao estudo das línguas começaram a se preocupar com as implicações que existem por trás do uso da língua, quando, por exemplo, um determinado dialeto é sinônimo de poder e prestígio social, ocupando uma posição de pretensa superioridade em relação às outras variedades. (Faria, 2009, p. 34)
}

Utilizando o conceito de normas proposto pelo teórico israelense Gideon Toury, avaliaremos se a maneira como as variantes linguísticas foram transpostas ao português foram normativas ou não normativas por parte dos tradutores na época em que foram produzidas. Fazem parte do corpus duas traduções da obra de Mark Twain: a de Monteiro Lobato, lançada inicialmente em 1934, e a de Maura Sardinha, assinada sob o pseudô- 
nimo Ganesha Consultoria Editorial, datada de 2011. Além de compararmos a postura dos tradutores perante os dialetos do texto-fonte, veremos também os paratextos que acompanham essas edições, além da visão que ambos expressaram acerca da atividade tradutória, quando este dado estiver disponível.

\section{Fundamentação teórica}

Inspirado pelo estruturalismo, Even-Zohar aponta uma nova forma de abordarmos a cultura: a teoria dos polissistemas. A ideia é "enfatizar a multiplicidade de interseções" (Even-Zohar, 2005, p. $3^{2}$ ) partindo-se da noção de que não há homogeneidade no sistema: o que imaginamos ser a cultura de um país, por exemplo, é apenas uma de suas culturas, aquela que ganha relevo e assume a posição central por ser legitimada pelas instituições detentoras de uma posição dominante na sociedade. Os outros sistemas ocupariam posições periféricas, travando uma luta constante pela centralidade. Segundo essa abordagem, para se compreender um sistema seria imprescindível estudar os diversos sistemas que o compõem e as conexões existentes entre eles.

Quem deu continuidade às ideias de Even-Zohar foi seu aluno, Gideon Toury, cuja obra, segundo Gentzler (2009), pode ser dividida em dois períodos. No início da década de 1970, o teórico se concentrou em estudos sociológicos acerca das condições culturais que influenciavam as traduções de obras literárias para a língua hebraica, utilizando como aparato teórico a teoria dos polissistemas. Concluiu que, apesar das poucas alterações no nível linguístico, a tendência era o texto-meta ter um estilo mais "elevado" em comparação com o texto-fonte. Instigado por tal resultado, percebeu que regras tácitas governavam o modo de se fazer traduções dentro desse polissistema e, de 1975 a 1980, tentou elaborar uma teoria mais abrangente que explicasse esse fato.

Assim, Toury criou o conceito de normas, um acordo estabelecido tacitamente entre os profissionais atuantes no mercado editorial em determinada época e local. As normas têm caráter diretivo, coercitivo, e nos pre-

\footnotetext{
${ }^{2}$ Tradução nossa, assim como todas as demais citações extraídas de obras publicadas em língua inglesa.
} 
dispõem a resolver problemas recorrentes de uma maneira específica, acatada por (quase) todos como a solução correta. No caso de dialetos, por exemplo, a tendência em uma época pode ser a de transformá-los em falas que sigam a norma-padrão e, em outra época, a de tentar recriá-las na língua-meta. Conforme explica Hermans:

\begin{abstract}
Se descartarmos as regularidades atribuíveis a diferenças estruturais entre as línguas envolvidas e nos concentrarmos nas escolhas não-obrigatórias, poderemos buscar restrições externas, socioculturais para explicar as preferências recorrentes que os tradutores demonstram. A essas restrições, Toury dá o nome de normas. São vistas como "instruções de desempenho". (Hermans, 1999, p. 75)
\end{abstract}

As normas entram em ação em todos os momentos que compõem a feitura de uma tradução. A norma inicial regula a escolha da obra e da estratégia tradutória adotada. Engloba, por exemplo, a decisão de se usar uma língua intermediária em vez de se fazer a tradução a partir do idioma do texto original. As normas preliminares dizem respeito à escolha do tradutor entre priorizar o texto-fonte ou a cultura-meta, e de certa forma é correlata às ideias de "estrangeirização" e "domesticação", termos de Venuti (2002) relativos à opção tradutória de deixar marcas da cultura-fonte que possam causar estranhamento no leitor, evidenciando a presença do tradutor, ou adequar ao público da cultura-meta os fatores do texto-fonte que remetam à cultura-fonte durante o ato tradutório, apagando os rastros desse ato. Deve-se levar em conta, entretanto, que a postura do tradutor em relação ao texto-fonte é influenciada pela posição do texto no polissistema da cultura-fonte. Durante o processo de tradução, estão em jogo as normas operacionais, influenciadas pela posição que a literatura traduzida ocupa no polissistema da cultura-alvo. Essas normas operacionais se subdividem em normas matriciais, que afetam o texto no nível macroestrutural, e normas linguístico-textuais, que afetam o nível microestrutural do texto.

Gentzler explica como o conceito de normas proposto por Toury deve ser utilizado a fim de averiguarmos a concepção do ato tradutório durante o preparo de textos-meta: 
[E]m termos de tradução, se quisermos distinguir tendências regulares, precisamos estudar não apenas textos individuais, mas sim traduções múltiplas do mesmo texto original, à medida que ocorrem em uma cultura receptora em diferentes épocas da história. (Gentzler, 2009, p. 163)

É importante ressaltar que Toury privilegia o polo receptor. Entretanto, no caso examinado consideramos importante destacar as características peculiares do texto-fonte, já que é através da comparação dele com os textos-meta que vemos claramente a postura prescrita pelo polissistema no qual estavam inseridos os tradutores. Assim, nesta pesquisa, utilizaremos as duas traduções de As aventuras de Huckleberry Finn para verificar se o parâmetro normativo em relação às traduções de diálogos realmente mudou nas últimas décadas.

\section{Uma breve descrição da roupagem das traduções de As aventuras de} Huckleberry Finn analisadas

Romance lançado nos Estados Unidos em janeiro de 1885, As aventuras de Huckleberry Finn foi bem recebido pela crítica, que destacou o êxito do autor na produção dos dialetos empregados pelos personagens. Por outro lado, foi alvo de polêmicas numerosas devido à presença constante da palavra nigger, considerada um termo pejorativo para os afro-americanos, e à denúncia que faz da escravidão no Sul do país. Explorando diversas variantes do inglês, Mark Twain deixa claras suas intenções em uma nota explicativa que antecede o romance em si:

\section{EXPLANATORY}

In this book a number of dialects are used, to wit: the Missouri negro dialect; the extremest form of the backwoods Southwestern dialect; the ordinary "Pike County" dialect; and four modified varieties of this last. The shadings have not been done in a haphazard fashion, or by guesswork; but painstakingly, and with the trustworthy guidance and support of personal familiarity with these several forms of speech.

I make this explanation for the reason that without it many readers would suppose that all these characters were trying to talk alike and not succeeding. 
THE AUTHOR

A tradução dessa nota explicativa é omitida na edição cuja tradução é assinada por Monteiro Lobato, o que já sinaliza a posição adotada no que tange aos dialetos presentes no texto-fonte. Tampouco consta da quartacapa qualquer menção às peculiaridades linguísticas do livro. Na edição traduzida por Ganesha Consultoria Editorial, quem assina as notas explicativas é Maura Sardinha. Por justificar as escolhas tradutórias em paratextos, presumimos que Sardinha seja a responsável pela versão. Nessa edição, a explicação do autor é mantida, seguida por uma "Nota da edição de bolso brasileira":

\footnotetext{
O texto explicativo de Mark Twain, aqui reproduzido na página 7, talvez baste para dar ao leitor um panorama das variadas nuances da linguagem empregada no romance. Vale ratificar que nenhum dos personagens é fiel às normas gramaticais e, portanto, tanto a grafia quanto a pontuação procuram imitar o ritmo da língua falada. Os verbos nem sempre concordam com o sujeito, substantivos que deviam estar flexionados não vão para o plural e muitas palavras aparecem com a grafia diferente dos verbetes dicionarizados. Com isso, a intenção desta tradução foi manter o caráter de oralidade que permeia todo o texto, oferecendo um matiz que varia de acordo com a origem social de cada personagem. (Twain, 2011, p. 9)
}

Além dessa nota, podemos também ressaltar a quarta-capa da edição da BestBolso, que também enfatiza a tentativa de reprodução das variantes orais na tradução. Após uma breve sinopse do romance, lê-se: "Nesta edição de bolso foi mantido o caráter de oralidade que permeia todo o texto e que varia de acordo com a região e a origem social de cada personagem." Além disso, há no final do livro uma nota explicativa assinada por Maura Sardinha relatando a maneira como lidou com as complexidades dessa tradução, sobre a qual falaremos mais adiante. Conclui-se, portanto, que nesse caso a tradução com marcas de oralidade é utilizada como um ponto positivo a ser considerado pelo leitor, instigando-o a escolher essa edição.

Na edição da BestBolso, há oito notas de rodapé no miolo do livro, sendo apenas uma delas assinalada como "N. da T.", explicando que "tem- 
perança" era um "movimento que pregava a abstinência total do álcool" (Twain, 2011, p. 33). As outras notas foram acrescidas pelo editor. As muitas notas da edição da Companhia Editora Nacional não são assinadas e explicam palavras que as crianças talvez desconheçam.

No que diz respeito ao público-alvo, a tradução de Monteiro Lobato, lançada pela Companhia Editora Nacional, é classificada como literatura infantojuvenil, recomendada a leitores a partir dos onze anos. Quanto às ilustrações, o livro apenas repete parte do desenho da capa na abertura de cada capítulo. Já na tradução de Maura Sardinha e edição da BestBolso, a obra é categorizada como ficção norte-americana, sem nenhuma classificação etária, o que nos leva a crer que a casa editorial trate o livro como um romance direcionado a adultos. Essa edição contém algumas ilustrações.

\section{Os tradutores e as normas vigentes em suas épocas}

\subsection{Monteiro Lobato e a tradução}

Monteiro Lobato (1882-1948) foi um grande escritor brasileiro de literatura infantojuvenil, famoso principalmente pela coleção de livros Sítio do Picapau Amarelo, publicado entre as décadas de 1920 e 1940. Segundo Milton (2002), Lobato teve duas editoras, Monteiro Lobato e Cia. e Companhia Editora Nacional, responsáveis por grande parte das obras literárias editadas no Brasil nessas décadas. Ao mesmo tempo em que via o livro como produto - preocupando-se bastante com a produção gráfica e as capas das obras que editava -, demonstrou seu idealismo em relação à literatura ao afirmar que um país era feito de livros e homens.

Nacionalista convicto, acreditava que, após quatrocentos anos de subserviência a Portugal, devíamos criar uma língua brasileira à parte. Sua postura no que tange à tradução, segundo relata Milton, seria considerada pouco ortodoxa atualmente:

\footnotetext{
Em carta de 1921, ele menciona os planos de produzir uma série de livros infantis "com mais leveza e humor" (...) do que as histórias lançadas previamente, organizadas por Jansen Muller, as quais ele retrabalharia e "aprimoraria". (...) Lobato ficava encasquetado com a linguagem usada nas traduções brasileiras lançadas pela editora Garnier, cujos donos eram franceses, e comentou "Temos que refazer tudo isso - abrasileirar a lin-
} 
guagem" (...), e recomendou ao tradutor Godofredo Rangel que ele tomasse a liberdade de melhorar o original quando necessário. Assim, a técnica de tradução de Lobato era a adaptação, usando uma linguagem mais simplificada, que seria imediatamente compreendida por crianças, seu público-alvo. (Milton, 2002, p. 125)

Foi seguindo esse parâmetro que Monteiro Lobato traduziu e adaptou obras como Peter Pan, Alice no País das Maravilhas, Robinson Crusoé, Tom Sawyer - também de autoria de Mark Twain - e As Viagens de Gulliver.

\title{
4.2. Maura Sardinha e a tradução
}

Após o encerramento do romance, há na edição da BestBolso sete páginas ocupadas por uma "Nota explicativa da tradutora". Nela, Maura Sardinha parte de questões teóricas sobre tradução, citando Meschonnic, Mounin, Steiner e Eco, entre outros estudiosos da área, para concluir que a antiga pergunta do que significa traduzir teve respostas diversas e divergentes ao longo da história:

\begin{abstract}
Uma breve olhada nas diferentes concepções de tradução no decorrer da história (...) nos mostra que as mesmas questões sempre existiram, variando as respostas que a elas foram dadas: traduções literais, palavra por palavra, por temor de "trair" o sentido original; traduções "melhoradas" pelo tradutor, as "belas infiéis", sob a justificativa de produzir um texto em maior conformidade com os cânones da língua de chegada; traduções substancialmente modificadas, aumentadas ou reduzidas, que hoje seriam chamadas de adaptações. Toda tradução depende do modo como o tradutor concebe a atividade da tradução, do projeto que tem para aquela tradução específica e do horizonte do tradutor. Uma mesma época pode dar respostas diferentes, permitindo a coexistência de posições conflitantes, dependendo do ponto de vista do tradutor. (Twain, 2011: 344-345)
\end{abstract}

Em seguida, Sardinha destaca a grande diferença entre a tradução de textos literários e textos de outros gêneros. Nesse ponto, enfatiza a importância do ritmo da narrativa para uma obra literária e, por conseguinte, a relevância de reproduzi-lo na tradução:

Em um texto eminentemente literário, (...) a exigência básica recairá na qualidade estética da reprodução do texto, atentando-se para o estilo, o 
ritmo, a escolha vocabular, a recriação, sempre que possível, das metáforas e outras figuras de linguagem e pensamento. Não teria cabimento, por exemplo, traduzir um texto de frases longas, predominantemente em discurso indireto, marcadamente escrito num registro culto e até refinado, recorrendo a períodos curtos, com uso abusivo do discurso direto, eivado de expressões vulgares, porque, ainda que o "sentido" da mensagem se mantivesse, todo o resto, que numa obra de arte é inseparável desse "sentido", teria se perdido. (Twain, 2011, p. 346)

Com um comentário mais aprofundado sobre a peculiaridade dos linguajares presentes no livro, a tradutora analisa a estratégia utilizada por Mark Twain na escrita dos diálogos da obra em questão:

\begin{abstract}
De saída, temos um afastamento no tempo e no espaço que não nos permite a tal "familiaridade pessoal com essas várias formas de falar" alegada pelo autor. Isso, sem entrar no mérito da questão de que o autor não teria, na verdade, dado a Huck o "dialeto negro do Missouri" usado para outros personagens, tendo tecido, na fala de Huck, elementos muito significativos do vocabulário, da gramática e da sintaxe que não faziam parte do inglês padrão ensinado nas escolas públicas, embora muito presentes na fala dos afro-americanos na época, fazendo da linguagem de Huck uma mescla dos dialetos dos brancos pobres e dos afro-americanos do Mississippi, assim forjando uma figura de identidade "racial" mista, que simboliza a mescla cultural e a diversidade do povo americano. (Twain,
\end{abstract} 2011, p. 347)

Maura Sardinha, então, justifica sua dificuldade em traduzir os dialetos de As aventuras de Huckleberry Finn, citando o fato de que não existe uma convergência de opiniões acerca da melhor maneira de fazê-lo, dado que não há equivalências perfeitas entre os falares que esses dialetos ocupam dentro da cultura americana e os dialetos de outros polissistemas linguísticos:

\footnotetext{
Além de contornar esse obstáculo, foi preciso enfrentar o fato de que, segundo conselhos de especialistas, no Brasil não se aceita bem que um texto narrado em primeira pessoa venha, todo ele, recheado de erros e vícios de linguagem.
}

Diante das diversas questões suscitadas pelo original, procuramos, de início, consultar outras versões da obra, no caso, as do francês, do espanhol e do português de Portugal, constatando que, de uma forma ou de outra, 
todas tentaram driblar o problema, quer uniformizando as falas, quer introduzindo um ou outro erro de sintaxe aqui e ali, mas sem conseguir reproduzir a contento a intenção do autor, ou seja, a recriação de diversos registros. Por isso, na tentativa de manter minimamente a diversidade das falas, recorremos a professores mais afeitos a essa problemática. (Twain, 2011, p. 347)

Para finalizar, Sardinha explica o método adotado para tentar reproduzir os diálogos do texto-fonte em português:

Tomamos, então, a liberdade de introduzir, no discurso de Huck e seus companheiros, as formas mais comuns da fala popular brasileira, ou seja, mistura de pronomes, concordâncias que fogem ao padrão, num registro bem coloquial. Na dos personagens negros, além das estruturas apontadas acima, os vícios de linguagem usuais entre segmentos menos favorecidos da população. Reservamos o português padrão, embora despretensioso e informal, para os adultos brancos, sem maiores distinções entre esta ou aquela região do Mississippi. Assim procedendo, acreditamos ter dado um certo colorido ao texto que, se nem de longe reproduz a riqueza do original, pelo menos não nivela ou uniformiza todas as falas. (Twain, 2011, p. 348)

A tradutora, assim, evidencia o interesse em recriar no texto-alvo as características dos diálogos do texto-fonte, adequando-o também às expectativas dos leitores.

\section{A norma na prática}

Veremos, a seguir, alguns exemplos das traduções de Monteiro Lobato e de Maura Sardinha. A comparação mostra claramente a forma com que cada um abordou a linguagem oral de Mark Twain. Se Lobato adequa os diálogos à norma-padrão, Sardinha se esmera para transpor ao português os traços singulares das falas dos personagens. A tradutora se sai melhor, conforme observaremos abaixo, nas falas de Jim, que lhe oferecem mais liberdade para subverter a norma-padrão.

\begin{tabular}{|c|c|c|}
\hline TEXTO-FONTE & MONTEIRO LOBATO & MAURA SARDINHA \\
\hline & & \\
\hline
\end{tabular}




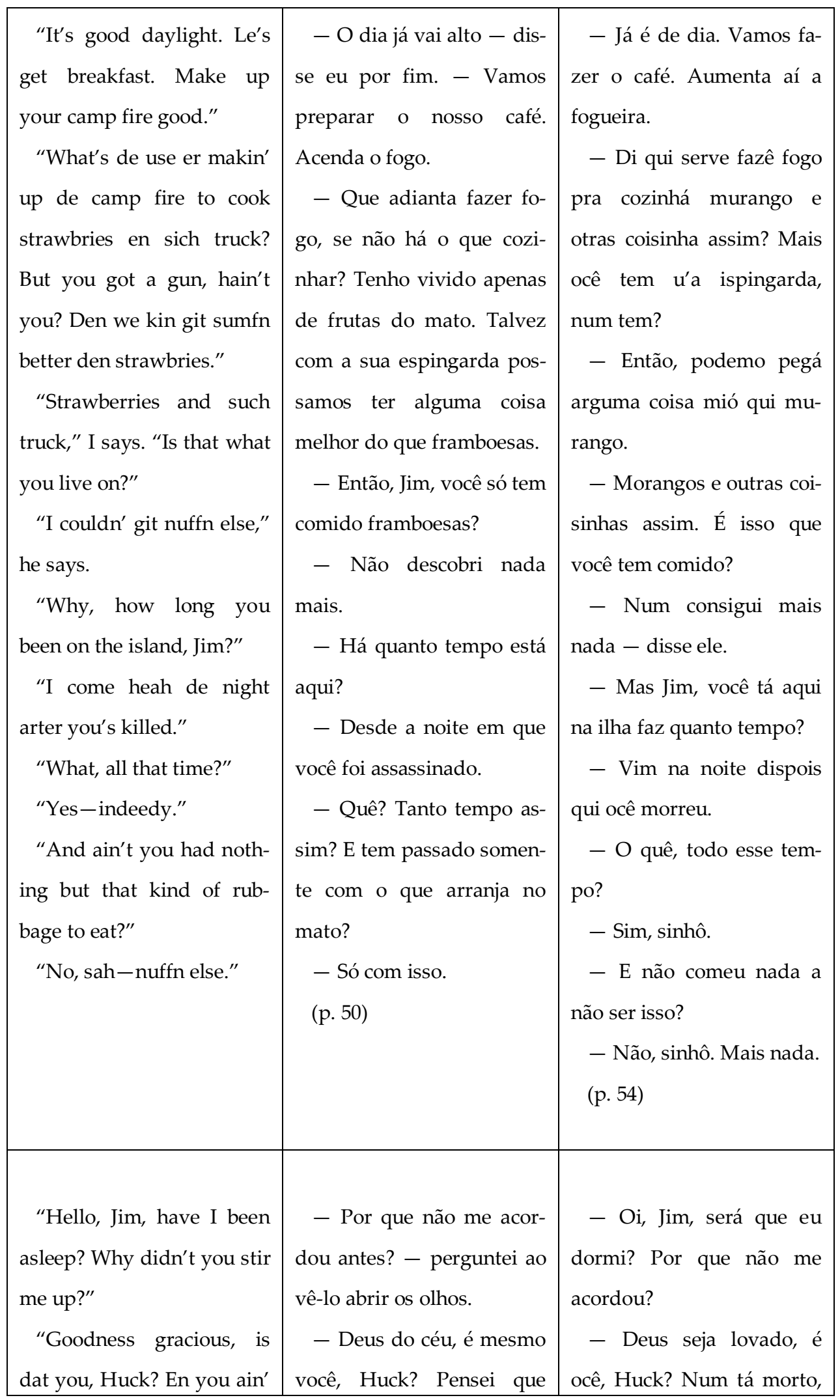




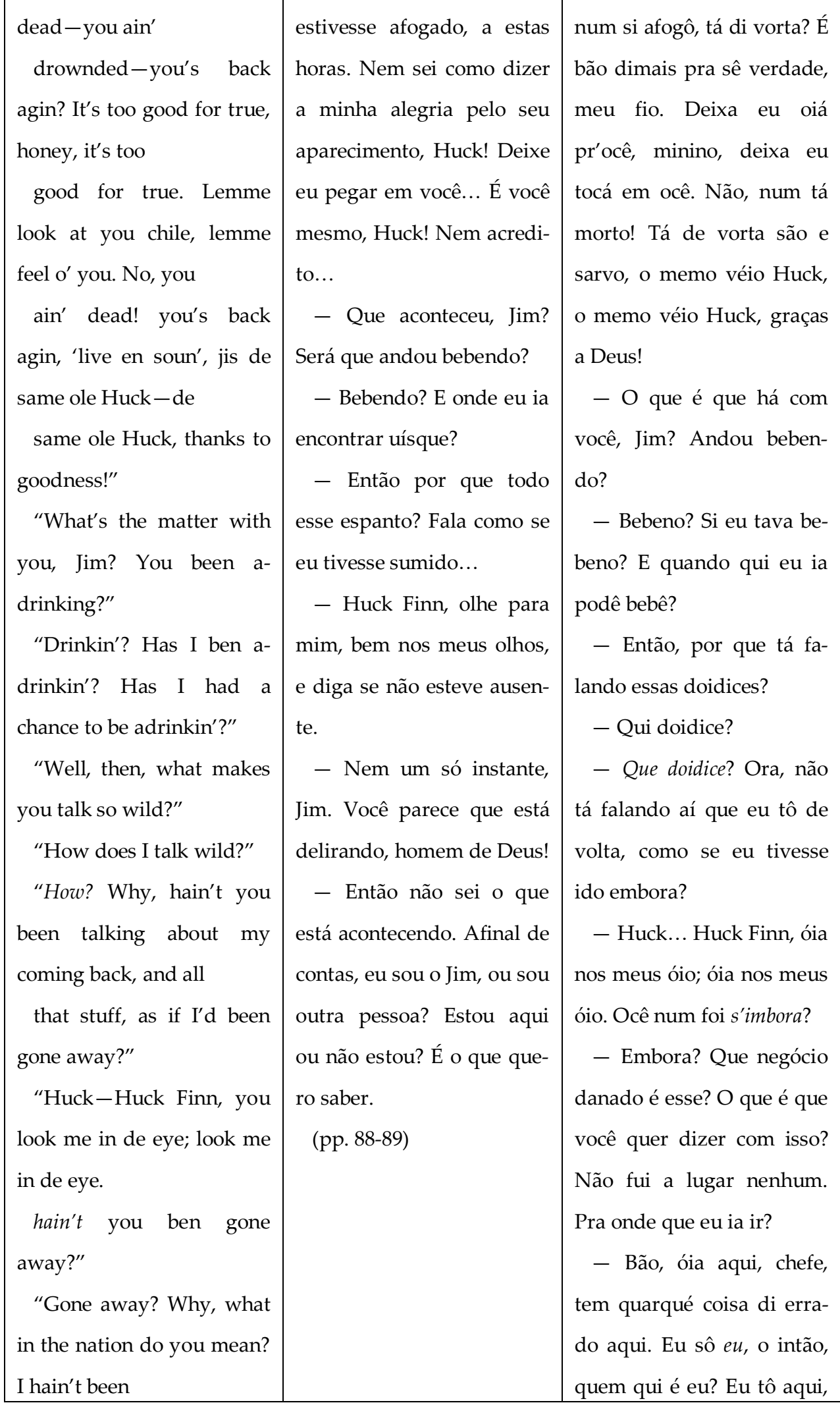




\begin{tabular}{|c|c|}
\hline $\begin{array}{l}\text { gone anywheres. Where } \\
\text { would I go to?" } \\
\text { "Well, looky here, boss, } \\
\text { dey's } \\
\text { sumf 'n wrong, dey is. Is I } \\
\text { me, or who is I? Is I heah, or } \\
\text { whah is I? Now dat's what } \\
\text { I wants to know." }\end{array}$ & $\begin{array}{l}\text { ou tô aonde? É isso qu'eu } \\
\text { quero sabê. } \\
\text { (pp. 99-100) }\end{array}$ \\
\hline
\end{tabular}

\section{Outros exemplos das normas atuantes em traduções de diálogos}

Em sua dissertação de mestrado, Johnwill Costa Faria (2009) compara traduções de Of Mice and Men, de John Steinbeck. Também marcado pelo uso de variantes dialetais, três traduções da obra, de diferentes épocas, foram comparadas pelo autor. Faria (2009) declara que

\footnotetext{
Na tradução de Of Mice and Men realizada por Veríssimo (Ratos e homens, edições de 1940 e 1968), o uso de um dialeto de prestígio nos diálogos em seu trabalho chama atenção, pois essa variedade, ainda que coloquial, destoa daquela utilizada pelo autor, John Steinbeck, uma variedade da língua inglesa estadunidense desprestigiada/estigmatizada. Em relação à tradução de Campello (1991), percebe-se maior aproximação relativa daquela variedade inglesa, em nível coloquial, mas que também ainda soa mais "educado" do que a língua dos personagens do texto de partida. A tradução de Ban (2005) é a que mais tenta se aproximar daquele inglês estigmatizado. (Faria, 2009, p. 79)
}

A conclusão obtida através da pesquisa e comparação empreendidas por Faria, portanto, corrobora a nossa impressão de que as "normas" adotadas na tradução de dialetos mudou, nas últimas décadas, da correção à tentativa de reprodução de peculiaridades contidas no texto-fonte. A constatação de que a tradução datada de 1991 já admite coloquialismos, mas não tanto quanto a tradução publicada em 2005, nos leva a conceber a hipótese de que a abertura do mercado editorial e do público leitor para a reprodução mais realista da oralidade se dilata cada vez mais. 
Entretanto, em sua tese de doutorado, em que analisa a tradução dos diálogos em romances de Agatha Christie ao longo do tempo, Vanessa Lopes Lourenço Hanes declara que "a representação do discurso oral em romances traduzidos de Agatha Christie pode ser resumida em duas palavras de peso: ortodoxia e dissidência" (Hanes, 2015, p. 197). Segundo a autora, o mercado editorial ainda rejeita o uso de registros mais baixos em obras impressas. Em artigo publicado em 2013, a mesma autora cogita que a utilização de registros mais baixos seja aceita somente em traduções de obras cujas variantes dialetais têm cunho sociocultural.

\section{Considerações finais}

Nesta pesquisa, verificamos que as normas adotadas para a tradução de variantes dialetais mudaram da década de 1940 para o início do século XXI. A postura de Monteiro Lobato, de retificar as falas que fogem à normapadrão, era considerada normal durante sua época, conforme indica Milton (2002), fato constatado também por Faria (2009) ao examinar a tradução de Érico Veríssimo para o romance Of Mice and Men, de Steinbeck. A preocupação de Maura Sardinha em explicar os problemas apresentados pelo texto-fonte e as escolhas que fez para solucioná-los parece indicar que as normas concernentes à tradução de dialetos vêm se alterando. Como o texto da quarta-capa geralmente é de autoria dos editores, a menção à oralidade da trama também demonstra que houve interesse por parte da casa editorial em destacar as características específicas da obra literária, respeitadas em sua tradução. Concluímos, assim, que as normas preliminares que pautaram essa tradução de As aventuras de Huckleberry Finn ditaram que se tentasse reproduzir a linguagem do texto-fonte no texto-meta. Pela reverência demonstrada ao texto de Mark Twain, podemos deduzir também que a tradução privilegia a "adequação", já que editores e tradutora escolheram não facilitar a leitura deturpando o registro utilizado no original.

Já na edição da Companhia Editora Nacional, a falta de paratextos pode ser vista como um indício de que As aventuras de Huckleberry Finn de Monteiro Lobato não são exatamente as mesmas propostas por Mark Twain. Entretanto, sua tradução, que segundo Toury seria aceitável, era compatível com o esperado à época. Além do que, sendo o tradutor e tam- 
bém o editor da edição, tanto as normas iniciais quanto as preliminares $\mathrm{e}$ operacionais - ou seja, toda a linha mestra do projeto - estavam sujeitas às preferências de Lobato.

Em suma, vimos que os parâmetros que regem as decisões editoriais e tradutórias, no que tange aos diálogos presentes em obras literárias, foram mudando no decorrer da história. Se na década de 1930 o tradutor podia consertar falas que fugiam à norma culta ao transpor o texto ao português, hoje a fidelidade ao texto-fonte é tida como fator positivo, explorada pela editora em paratextos a fim de agradar ao público comprador de livros, ainda que a presença de variantes linguísticas se restrinja às traduções de obras literárias em que elas exercem um papel marcadamente político. No entanto, a tentativa de reproduzir o registro desses romances indica que as portas do mercado editorial estão se abrindo para as marcas de oralidade. Quiçá, além da alteração das normas que pautam as traduções, possamos citar também como agente dessa mudança o acesso às informações sobre o original, atualmente facilitado pela internet - aumentando a expectativa dos leitores brasileiros quanto à fidelidade do texto-meta.

\section{Referências}

BRITTO, Paulo Henriques. A tradução literária. Rio de Janeiro: Civilização Brasileira, 2012.

EVEN-ZOHAR, Itamar. Polysystem Studies: Polysystem Theory (Revised). In: Papers in Culture Research. Tel-Aviv: Porter Chair of Semiotics (Temporary electronic book), 2005. pp. 1-11.

FARIA, Johnwill Costa. Of Mice and Men, de John Steinbeck: a oralidade na literatura como problema de tradução. Brasília, 2009. Dissertação (Mestrado em Letras). Instituto de Letras, UnB.

GENTZLER, Edwin. Teoria dos polissistemas. Teorias contemporâneas da tradução. Tradução de Marcos Malvezzi. São Paulo: Madras, 2009.

HANES, Vanessa Lopes Lourenço. A tradução de variantes orais da língua inglesa no português do Brasil: uma aproximação inicial Scientia Traductionis, n.13, 2013, p. 178-196.

. The Language of Translation in Brazil: Written Representations of Oral Discourse in Agatha Christie. Florianópolis, 2015. Tese (Doutorado em Estudos da Tradução) - Programa de Pós-graduação em Estudos da Tradução, Universidade Federal de Santa Catarina. 
HERMANS, Theo. Working with norms. Translation in Systems. Manchester: St. Jerome Publishing, 1999.

Translational Norms and Correct Translations. Translation Studies: The State of the Art. Amsterdam/Atlanta: Rodopi, 1991.

MILTON, John. Monteiro Lobato and Translation: Um país se faz com homens e livros. In: D.E.L.T.A., 19:ESPECIAL, 2002 (117-132).

TOURY, Gideon. The Nature and Role of Norms in Translation. Descriptive Translation Studies and Beyond. Amsterdam/Philadelphia: John Benjamins, 1995, p. 53-69.

TWAIN, Mark. As aventuras de Huckleberry Finn. Tradução de Ganesha Consultoria Editorial. Rio de Janeiro: BestBolso, 2011. As aventuras de Huckleberry Finn. Tradução de Monteiro Lobato. São Paulo: Companhia Editora Nacional, 2005. The Adventures of Huckleberry Finn.

http://twain.lib.virginia.edu/huckfinn/huchompg.html. Acesso em 10 de junho de 2015.

VENUTI, Lawrence. Escândalos da Tradução: por uma ética da diferença. Tradução de Laureano Pelegrin, Lucinéia Marcelino Villela, Marileide Dias Esqueda e Valéria Biondo; revisão técnica de Stella Tagnin. Bauru: EDUSC, 2002.

Resumo: A partir da breve análise de duas traduções separadas por décadas de As aventuras de Huckleberry Finn, de Mark Twain, do inglês ao português brasileiro, percebemos claramente que houve a tentativa de preservar as variantes dialetais do original na tradução mais recente, ao contrário do que ocorria anteriormente. Utilizando o conceito de normas proposto por Gideon Toury, tentamos explicar essa mudança de paradigma que parece estar acontecendo em relação às marcas de oralidade na tradução de obras literárias.

Palavras-chave: Mark Twain, oralidade, tradução, Toury; normas.

Abstract: Through a brief analysis of two translations separated by decades of The Adventures of Huckleberry Finn, by Mark Twain, from English into Brazilian Portuguese, it is noticeable that the most recent one attempts to preserve the dialects from the original text, unlike occurred previously. Using the concept of norms as presented by Gideon Toury, we try to explain this paradigm shift that seems to be occurring with respect to oral discourse in translations of literary works.

Keywords: Mark Twain, orality, translation, Toury, norms 